\title{
Food handling practice and associated factors among food handlers in public food establishments, Northwest Ethiopia
}

\author{
Fasikaw Adbarie Chekol ${ }^{1}$, Melkitu Fentie Melak ${ }^{2 *}$, Aysheshim Kassahun Belew ${ }^{2}$ and Ejigu Gebeye Zeleke ${ }^{3}$
}

\begin{abstract}
Objective: The objective of this study was to assess food handling practice and associated factors among food handlers in public food establishments, Northwest Ethiopia.

Results: In this study a total of 416 food handlers were participated with a response rate of 416 (98.6\%). Proportion of good food handling practice was 167 (40.1\%) [95\% Cl (confidence interval): 35.10, 44.50]. Work experience [AOR (adjusted odds ratio):1.95, 95\% Cl 1.11,3.45], good attitude $(A O R=1.97,95 \% \mathrm{Cl}=1.04,3.72)$, secondary school education level (AOR 2.91, Cl 1.20, 7.01), diploma and above education level (AOR 4.33, 95\% Cl 1.41, 13.31), use of three compartment dish-washing system (AOR 2.47, $\mathrm{Cl} 1.27,4.80$ ) and use of refrigerator (AOR 3.93, Cl 1.79, 8.63) were factors statistically associated with good food handling practice. This study indicated that food handling practice was relatively poor. Work experience, good attitude, level of education, use of three compartment dishwashing systems and refrigerator were factors associated with food handling practice. Hence, structuring the kitchen with modern dish washing system and refrigerator would enhance good food handling practice.
\end{abstract}

Keywords: Food handling practice, Food handler, Debark, Ethiopia

\section{Introduction}

Food can be contaminated from production up to consumption. Producers, shippers, processors, distributers and food handlers have the responsibility in ensuring the safety of food [1]. Particularly, in public food establishments, food handlers are the first responsible bodies to contaminate food by acting as either a biological or a physical carrier for many pathogenic organisms [2]. The degree of food contamination is highly determined by the degree of contact [2,3].

Food contamination mainly occurs through poor food handling practice which results in numerous food borne diseases. These diseases are the major causes of morbidity and mortality. Globally, more than $50 \%$ of the total food poisoning cases were attributed to improper food handling procedure [4]. Around 600 million food

\footnotetext{
*Correspondence: melkitu12@gmail.com

${ }^{2}$ Institute of Public Health Department of Human Nutrition, College of Medicine and Health Sciences, University of Gondar, Gondar, Ethiopia Full list of author information is available at the end of the article
}

borne illnesses and 420,000 deaths occur each year due to poor food handling practice [5]. Among ten people, one becomes ill from ingestion of contaminated food [5, 6]. In developing countries, approximately 10 to $20 \%$ of food-borne disease (FBD) outbreaks are due to food contamination [2]. South-east Asia and Africa constitutes the highest burden [7]. Around 700,000 people die due to FBD in sub-Saharan Africa [8]. In Ethiopia, though there is limited data, there were 280,458 out-patient cases in 2013 [9].

Hazardous pathogens and physical hazards like hand watch may causes life threatening health problems if they come in contact with food [2, 10-13]. Such Contaminants get access to contaminate food mainly due to food handler's poor knowledge and negligence during handling activities. Moreover, low financial resources, inadequacy food safety law, in availability of food establishment guideline and standards, as well as poor monitoring and evaluation system of food establishments play an important role in food handling practice $[1,14]$.

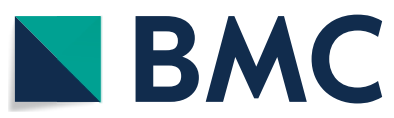

(c) The Author(s) 2019. This article is distributed under the terms of the Creative Commons Attribution 4.0 International License (http://creativecommons.org/licenses/by/4.0/), which permits unrestricted use, distribution, and reproduction in any medium, provided you give appropriate credit to the original author(s) and the source, provide a link to the Creative Commons license, and indicate if changes were made. The Creative Commons Public Domain Dedication waiver (http://creativecommons.org/ publicdomain/zero/1.0/) applies to the data made available in this article, unless otherwise stated. 
In Ethiopia, the coordination activities particularly at lower levels of government bodies are so weak. There is no clearly defined responsibility to control, monitor and evaluate food handlers of food establishments [9]. Ethiopian Studies conducted in Diredawa and Arbaminch showed that prevalence of good food handling practice was $52.4 \%$ and $32.6 \%$ respectively $[15,16]$.

Therefore, it is crucial to conduct a repeated study aiming at assessing food handling practice and associated factors among food handlers in public food establishments in Debark town, North-west Ethiopia.

\section{Main text Methods}

An institution based cross-sectional study was conducted from January 1 to 25, 2018 in Debark town, Northwest Ethiopia. The town is located $826 \mathrm{~km}$ Northwest of Addis Ababa, capital of Ethiopia. Within the town, there are 32 restaurants, 24 hotels, 49 cafes, 8 butcher houses and 3 juice houses which provide food for the catchment population and guests. All food handlers who were working in selected public food establishments in Debark town were the study population.

Sample size was estimated using single population proportion formula by considering food handling practice $52.4 \%$ [16], 5\% margin of error at 95\% confidence level and adding $10 \%$ non response rate the final sample size was 422 . This study comprises selecting public food establishments like hotels, restaurants, cafes, butcher shops and juice houses. Proportional allocation was done and 170,189,166, 22 and 4 food handlers were recruited from hotels, restaurants, cafes, butcher and juice houses respectively. Finally, simple random sampling technique was used to select 422 food handlers.

Food handling practice was computed by using 21 questions and 29 observational check-lists totally 50 questions. Accordingly, participants who respond 70\% and above considered as having good food handling practice whereas those who respond below $70 \%$ considered as having poor food handling practice $[16,17]$. Knowledge towards food handling was assessed by 20 questions and participants who respond $70 \%$ and above considered as having good knowledge whereas below $70 \%$ were considered as having poor knowledge [16, 17]. Ten questions were used to assess attitude towards good food handling and participants who respond $80 \%$ and above considered as having good attitude whereas below $80 \%$ considered as having poor attitude [14].

Data was collected using structured interviewer administered questionnaire and observational checklist. It was adopted from World Health Organization (WHO) [3] and published studies with some modifications by adding socio-demographic variables, knowledge, attitude of food handler and sanitary condition of the food establishments. Pre-test was done on $5 \%$ food handlers found in a nearby town and necessary amendments were made. Close supervision was done during data collection. Completeness of the collected data was checked daily. Data were coded and entered into EPI info version 7 and then exported to SPSS version 20 statistical package for analysis. Descriptive statistics was carried out. Binary logistic regression model was employed and variables having $\mathrm{p}$-value of $<0.2$ were exported to multi-variable binary logistic regression model to identify confounders. Adjusted odds (AOR) with $95 \% \mathrm{CI}$ and $\mathrm{p}$ value $<0.05$ was used to show association. Variables having p-value $\leq 0.05$ were taken as significantly associated with good food handling practice (Additional file 1).

\section{Results}

\section{Socio-demographic characteristics of food handlers}

In this study a total of 416 food handlers were participated with a response rate of 416 (98.6\%). Majority 379 $(91.9 \%)$ of the participants were females. The median age of respondents was 21 years with inter-quartile range of \pm 7 . Of the total, $85.3 \%$ had taken primary education and above. Regarding monthly income, more than half 282 (67.8\%) were earned 200-600 Ethiopian birr (Table 1).

\section{Knowledge and attitude of food handlers}

Three hundred twenty-nine (79.1\%) and 289 (69.5\%) of respondents were found to have good knowledge and good attitude towards food handling practice respectively.

\section{Institutional characteristics}

All public food establishments had pipe water supply. About three-fourth 307 (73.8\%) and majority 346 (83.2\%) of respondents handled food in an institution having three compartment dishwashing system and functional toilet facility respectively. However, half 211 (50.7\%) of respondents handled food in food establishments where there were no liquid waste storage (Table 2).

\section{Food handling practice}

In this study, the overall magnitude of good food handling practice was $40.1 \%$ (95\% CI 35.10, 44.50).

\section{Factors associated with food handling practice}

Multi variable logistic regression output showed that work experience in different food establishments, good attitude, secondary school and diploma and above education levels, use of three compartment dishwashing system and refrigerator in the kitchen were factors associated with good food handling practice. 
Table 1 Socio-demographic characteristics of food handlers working in public food establishments in Debark town, North-west Ethiopia, $2018(\mathrm{n}=416)$

\begin{tabular}{|c|c|c|c|}
\hline Variables & Category & Frequency (n) & Percent (\%) \\
\hline \multirow[t]{2}{*}{ Sex } & Female & 379 & 91.9 \\
\hline & Male & 37 & 8.9 \\
\hline \multirow[t]{4}{*}{ Age in years } & $<18$ & 117 & 28.1 \\
\hline & $18-21$ & 106 & 25.5 \\
\hline & $22-25$ & 94 & 22.6 \\
\hline & $>25$ & 99 & 23.8 \\
\hline \multirow[t]{2}{*}{ Religion } & Orthodox & 394 & 94.7 \\
\hline & Muslim & 22 & 5.3 \\
\hline \multirow{2}{*}{$\begin{array}{l}\text { Current marital } \\
\text { status }\end{array}$} & Unmarried & 326 & 78.4 \\
\hline & Married & 90 & 21.6 \\
\hline \multirow[t]{4}{*}{ Educational level } & Informal & 61 & 14.7 \\
\hline & Primary (1-8) & 154 & 37 \\
\hline & Secondary (9-12) & 156 & 37.5 \\
\hline & Diploma and above & 45 & 10.8 \\
\hline \multirow[t]{3}{*}{ Job responsibility } & Cooker & 207 & 49.8 \\
\hline & Waiter & 174 & 41.8 \\
\hline & Washer & 35 & 8.4 \\
\hline \multirow[t]{3}{*}{ Monthly income } & $<200$ birr & 27 & 6.5 \\
\hline & 200-600 birr & 282 & 67.8 \\
\hline & $>600$ & 107 & 25.7 \\
\hline \multirow{2}{*}{$\begin{array}{l}\text { Work experience in } \\
\text { different public } \\
\text { food establish- } \\
\text { ments }\end{array}$} & Yes & 127 & 30.5 \\
\hline & No & 289 & 69.5 \\
\hline \multirow{3}{*}{$\begin{array}{l}\text { Work experience } \\
\text { (years) }\end{array}$} & $<1$ & 215 & 51.7 \\
\hline & $1-3$ & 116 & 27.9 \\
\hline & $>3$ & 85 & 20.4 \\
\hline \multirow[t]{2}{*}{ Training } & Yes & 29 & 7 \\
\hline & No & 387 & 93 \\
\hline \multirow[t]{2}{*}{ License } & Yes & 28 & 6.7 \\
\hline & No & 388 & 93.3 \\
\hline \multirow{2}{*}{$\begin{array}{l}\text { Supervision by gov- } \\
\text { ernment/owner/ } \\
\text { manager }\end{array}$} & Yes & 199 & 47.8 \\
\hline & No & 217 & 52.2 \\
\hline \multirow[t]{2}{*}{ Feedback } & Given & 338 & 81.3 \\
\hline & Not given & 78 & 18.8 \\
\hline \multirow[t]{2}{*}{ Medical checkup } & Yes & 59 & 14.2 \\
\hline & No & 357 & 85.8 \\
\hline \multirow[t]{3}{*}{ Deworming } & None & 399 & 95.9 \\
\hline & Only once & 13 & 3.1 \\
\hline & Twice a year & 4 & 1 \\
\hline \multirow[t]{2}{*}{ Working hour } & $<8 \mathrm{~h}$ & 93 & 22.4 \\
\hline & $\geq 8 \mathrm{~h}$ & 323 & 77.6 \\
\hline
\end{tabular}

The odds of performing good handling practice among food handlers who had work experience in different public food establishments was two folds higher as compared to those food handlers who had no experience of work in such institutions $(\mathrm{AOR}=1.95,95 \% \mathrm{CI} 1.11,3.45)$.

Similarly, the odds of performing good handling practice among food handlers who had good attitude towards good food handling practice was twofolds higher as compared to their counterparts $(\mathrm{AOR}=1.97,95 \% \mathrm{CI} 1.04$, 3.72).

The result also showed that the odds of performing good food handling practice among food handlers who attended secondary school (grade 9-12) was three folds $(\mathrm{AOR}=2.91, \mathrm{CI} 1.20,7.01)$ and those who had diploma and above was four and half folds $(\mathrm{AOR}=4.33$, CI 1.41, 13.31) higher as compared to those food handlers who were informally educated (illiterate and can read and write).

In addition, the likelihood of performing good food handling practice among food handlers who used three compartment dishwashing system was two and half folds $(\mathrm{AOR}=2.47$, CI 1.27, 4.80) higher than those food handlers who handled without using three compartment dishwashing system.

Furthermore, the odds of performing good food handling practice among food handlers who had functional refrigerator in their kitchen four folds $(\mathrm{AOR}=3.93$, CI 1.79, 8.63) higher as compared to those food handlers who had no functional refrigerator in their kitchen (Table 3).

\section{Discussion}

Improper food handling practice is one of the major routes for food born disease transmission. An emphasis need to be given for food handling practice by the concerned bodies. Therefore, this study provides an insight on status of food handling practice on the area. This study revealed that good food handling practice was $40.1 \%$ (95\% CI 35.10, 44.50). The result is consistent with the study conducted in Nigeria $36.50 \%$ [18].

However, the finding is lower than other studies conducted in Malaysia 59.30\% [19], Jordan 89.43\% [20]. The variation might come across due to study settings. The study in Malaysia was conducted in university campus where as in Jordan the study was conducted in hospital. In fact, these institutions assumed to have adequate resources and suitable setup for food handling practice as compared to this study. In addition to this, the education level of food handlers in Malaysia and Jordan might 
Table 2 Institutional characteristics of food handling practice among food handlers working in public food establishments in Debark town, North-west Ethiopia, $2018(n=416)$

\begin{tabular}{|c|c|c|c|}
\hline Variables & Category & Frequency (n) & Percent (\%) \\
\hline \multirow[t]{2}{*}{ Liquid waste storage system } & Yes & 205 & 49.3 \\
\hline & No & 211 & 50.7 \\
\hline \multirow[t]{4}{*}{ Type of liquid waste storage system } & Open space & 179 & 43 \\
\hline & Sewage pit & 140 & 33.7 \\
\hline & Septic tank & 67 & 16.1 \\
\hline & Storm draining water & 24 & 5.8 \\
\hline \multirow[t]{2}{*}{ Insects or rodents breeding around establishment } & Yes & 112 & 26.9 \\
\hline & No & 304 & 73.1 \\
\hline \multirow[t]{2}{*}{ Functional kitchen } & Yes & 353 & 84.9 \\
\hline & No & 63 & 15.1 \\
\hline \multirow[t]{2}{*}{ Functional shower facility } & Yes & 159 & 38.2 \\
\hline & No & 257 & 61.8 \\
\hline \multirow[t]{2}{*}{ Clean utensils availability } & Yes & 363 & 87.3 \\
\hline & No & 53 & 12.7 \\
\hline \multirow[t]{2}{*}{ Shelf/cupboard availability } & Yes & 241 & 57.9 \\
\hline & No & 175 & 42.1 \\
\hline \multirow[t]{2}{*}{ Functional refrigerator in the kitchen } & Yes & 115 & 27.6 \\
\hline & No & 301 & 72.4 \\
\hline \multirow[t]{2}{*}{ Separate dressing room for food handler } & Yes & 97 & 23.3 \\
\hline & No & 319 & 76.7 \\
\hline
\end{tabular}

contribute to the variation. Proportion of food handlers who attended secondary school and above were $77 \%$ and 94\% in Malaysia and Jordan studies respectively where as in this study only $48.3 \%$. As education level progresses, food handlers would have improved knowledge and attitude towards good food handling practice [21].

The result of this study is also lower than studies conducted in Dangla 52.5\% [2], Dire Dawa 52.4\% [16]. The discrepancy might be due to that a study conducted in Dangla used mean as cut off point to determine the prevalence of food handling practice but in this study percentage was used. Sensitivity of food to hot environment in Diredawa might make food handlers curious while handling [16] because foods may become easily perishable.

However, the results of this study is higher than other studies conducted in Gondar 30.3\% [14], Gamogofa $32.6 \%$ [15]. This might be due to difference in year of study and cut off points used. The study conducted in Gondar town got around 5 years long. Due to globalization access of information improved from time to time and food handlers can develop good knowledge and positive attitude towards food handling so that they could perform good handling practice relatively better [22]. In addition to this, the cut off points used to determine food handling practice were different $(80-100 \%=$ good, $60-79 \%=$ fair and $<60 \%=$ poor $)$ as compared to this study in which food handling practice was determined in two levels using the minimum cut off point $(\geq 70 \%=$ good and $<70=$ poor $)[16,17]$. Obviously, the cut-off point variation entirely alters the results of the study. In Gamogofa interviewees were mostly males and having primary school and below $68.66 \%$ as compared to this study in which only $8.9 \%$ of males and $51.7 \%$ of primary and below education level of respondents involved. This is because females had more experience even in their day to day home activity than males and low education level of food handlers will have poor knowledge and attitude so that not liable to apply basic good food handling principles [16].

The odds of performing good handling practice among food handlers who had experience was 1.95 times higher as compared to those who hadn't. The possible explanation to this could be because experience could help food handlers to acquire better knowledge and skills regarding food handling practice.

Similarly, the odds of performing good handling practice among food handlers who had good attitude towards good food handling practice was 1.97 times higher as compared to their counterparts. Those who have good attitude are assumed to have good knowledge which is the foundation of skill/practice. This is also evidenced by other studies Gondar [14] and Diredawa [16].

The odds of performing good food handling practice among food handlers who had diploma and above 4.33 
Table 3 A bi-variable and multi-variable logistic regression analysis output of associated factors with food handling practice in Debark town, North-west Ethiopia, $2018(n=416)$

\begin{tabular}{|c|c|c|c|c|}
\hline \multirow[t]{2}{*}{ Variable } & \multicolumn{2}{|l|}{ Practice } & \multirow[t]{2}{*}{$\operatorname{COR}(95 \% \mathrm{Cl})$} & \multirow[t]{2}{*}{ AOR $(95 \% \mathrm{Cl})$} \\
\hline & Good & Poor & & \\
\hline \multicolumn{5}{|l|}{ Monthly income } \\
\hline$<200$ & $8(29.6 \%)$ & 19 (70.4\%) & 1 & 1 \\
\hline $200-600$ & $98(34.8 \%)$ & 184 (65.2\%) & $1.27(0.53-2.99)$ & $0.45(0.15-1.35)$ \\
\hline$>600$ & $61(57 \%)$ & $46(43 \%)$ & $3.15(1.27-7.83)$ & $0.35(0.10-1.25)$ \\
\hline \multicolumn{5}{|l|}{ Work experience (year) } \\
\hline$<1$ & $72(33.5 \%)$ & $143(66.5 \%)$ & 1 & 1 \\
\hline $1-3$ & $54(46.6 \%)$ & $62(53.4 \%)$ & $1.73(1.09-2.75)$ & $1.27(0.69-2.35)$ \\
\hline$>3$ & $41(48.2 \%)$ & $44(51.8 \%)$ & $1.85(1.11-3.09)$ & $1.57(0.74-3.32)$ \\
\hline \multicolumn{5}{|l|}{ Working hour (h) } \\
\hline$\leq 8$ & 137 (32.3\%) & 186 (67.7\%) & 1 & 1 \\
\hline$>8$ & $30(42.4 \%)$ & $63(57.6 \%)$ & $0.65(0.40-1.05)$ & $0.56(0.30-1.05)$ \\
\hline \multicolumn{5}{|c|}{ Work experience in different public food establishments } \\
\hline Yes & $70(55.1 \%)$ & $57(44.9 \%)$ & $2.43(1.59-3.72)$ & $1.95(1.11-3.45)^{*}$ \\
\hline No & $97(33.6 \%)$ & $192(64.4 \%)$ & 1 & 1 \\
\hline \multicolumn{5}{|l|}{ Training } \\
\hline Yes & $18(62.1 \%)$ & $11(37.9 \%)$ & $2.61(1.20-5.69)$ & $1.33(0.35-4.98)$ \\
\hline No & $149(38.5 \%)$ & $238(61.5 \%)$ & 1 & 1 \\
\hline \multicolumn{5}{|l|}{ License } \\
\hline Yes & $18(64.3 \%)$ & $10(35.7 \%)$ & $2.89(1.30-6.42)$ & $0.92(0.24-3.54)$ \\
\hline No & 149 (38.4\%) & $239(61.6 \%)$ & 1 & 1 \\
\hline \multicolumn{5}{|l|}{ Supervision } \\
\hline Yes & $98(49.2 \%)$ & $101(50.8 \%)$ & $2.01(1.40-3.10)$ & $1.30(0.78-2.16)$ \\
\hline No & $69(31.8 \%)$ & 148 (68.2\%) & 1 & 1 \\
\hline \multicolumn{5}{|l|}{ Medical check-up } \\
\hline Yes & $36(61.0 \%)$ & $23(39.0 \%)$ & $2.70(1.53-4.75)$ & $0.96(0.43-2.19)$ \\
\hline No & $131(36.7 \%)$ & $226(33.3 \%)$ & 1 & 1 \\
\hline \multicolumn{5}{|l|}{ Building ownership } \\
\hline Owned & 104 (49.1\%) & 108 (50.9\%) & $2.16(1.44-3.22)$ & $1.15(0.65-2.04)$ \\
\hline Rented & $63(30.9 \%)$ & 141 (69.1\%) & 1 & 1 \\
\hline \multicolumn{5}{|l|}{ Attitude } \\
\hline Good & 132 (45.7\%) & $157(54.3 \%)$ & $2.21(1.41-3.48)$ & $1.97(1.04-3.72)^{*}$ \\
\hline Poor & $35(27.6 \%)$ & 92 (72.4\%) & 1 & 1 \\
\hline \multicolumn{5}{|l|}{ Knowledge } \\
\hline Good & 145 (44.1\%) & 184 (55.9\%) & $2.33(1.37-3.96)$ & $1.31(0.64-2.65)$ \\
\hline Poor & $22(25.3 \%)$ & $65(74.7 \%)$ & 1 & 1 \\
\hline \multicolumn{5}{|l|}{ Level of education } \\
\hline Informal & $14(23.0 \%)$ & $47(77.0 \%)$ & 1 & 1 \\
\hline Primary & $51(33.1 \%)$ & 103 (69.9\%) & $1.68(0.84-3.30)$ & $1.83(0.76-4.40)$ \\
\hline Secondary & $82(47.4 \%)$ & $74(52.6 \%)$ & $3.03(1.54-5.95)$ & $2.91(1.20-7.01)^{*}$ \\
\hline Diploma and above & $28(62.2 \%)$ & $17(37.8 \%)$ & $5.53(2.37-12.91)$ & $4.33(1.41-13.31)^{* *}$ \\
\hline \multicolumn{5}{|c|}{ Three compartment dishwashing system } \\
\hline Yes & $149(48.5 \%)$ & $158(51.5 \%)$ & $4.77(2.74-8.29)$ & $2.47(1.27-4.80)^{*}$ \\
\hline No & $18(16.5 \%)$ & $91(83.5 \%)$ & 1 & 1 \\
\hline \multicolumn{5}{|l|}{ Liquid waste disposal } \\
\hline Yes & $102(49.8 \%)$ & $103(50.2 \%)$ & $2.22(1.49-3.32)$ & $1.29(0.77-2.16)$ \\
\hline No & $65(30.8 \%)$ & $146(69.2 \%)$ & 1 & 1 \\
\hline
\end{tabular}


times higher as compared to those having no formal education. The result is supported by studies conducted in Italy [23], Jordan [20], Ghana [24], Diredawa [16], Nigeria [25] and Addis Ababa [21].

The likelihood of performing good food handling practice among food handlers who used three-compartment dishwashing system was 2.47 higher than don'ts. Moreover, the odds of performing good food handling practice among food handlers who had a functional refrigerator 3.93 times higher as compared to those who had no. This might be explained by better institutional infrastructure support and enhances better food handling practice [26]. This is in line with a study conducted in Diredawa [16].

In this study, food handling practice was relatively poor. Work experience, good attitude, level of education, use of three compartment dishwashing systems and refrigerator were factors associated with food handling practice. Food establishments better to hire food handlers having experience and secondary education and above. In addition, it is better to structuring the kitchen with modern dishwashing system and refrigerator.

\section{Limitations}

The study might be liable to social desirability and recall bias. In addition, the cross-sectional nature of the study might affect the cause and effect relationship. Moreover, parasitic and microbiological laboratory analyses were not considered in this study.

\section{Additional file}

Additional file 1. Questionnaires.

\section{Abbreviations}

AOR: adjusted odds ratio; $\mathrm{Cl}$ : confidence interval; COR: crude odds ratio; FBDs: food borne diseases; IRB: Institutional Review Board; SPSS: statistical package for social sciences; WHO: World Health Organization.

\section{Authors' contributions}

FA contributed in the generation of the topic, preparation of proposal, data collection, analyses and development of the manuscript. EG, MF and AK contributed in reviewing the proposal, data analysis and development of the manuscript and critical review of final manuscript. All authors read and approved the final manuscript.

\section{Author details}

1 Dabat District Health Office, North Gondar Zonal Health Office, Amhara Regional Health Bureau, Dabat, Ethiopia. ${ }^{2}$ Institute of Public Health Department of Human Nutrition, College of Medicine and Health Sciences, University of Gondar, Gondar, Ethiopia. ${ }^{3}$ Institute of Public Health Department of Epidemiology and Biostatistics, College of Medicine and Health Sciences, University of Gondar, Gondar, Ethiopia.

\section{Acknowledgements}

The researchers want to acknowledge Debark culture and tourism and health offices for their kind help. Author's heartfelt acknowledgement goes to the study participants, data collectors and supervisors.

\section{Competing interests}

The authors declare that they have no competing interests.

\section{Availability of data and materials}

Data will be available up on the request of the corresponding author.

\section{Consent for publication}

Not applicable.

\section{Ethics approval and consent to participate}

Ethical clearance was obtained from Ethical Review Board of University of Gondar, College of Medicine and Health Sciences, Institute of Public Health (Ref.No/IPH/158/2017) prior to data collection. Written informed consent was obtained from each study participant after the purpose of the study explained. Food handlers who were not volunteer to continue from the beginning or from any part of the interview were respected to do so. Privacy and strict confidentiality were maintained during the interview process. Name and personal identifiers of participants had not been included in order to maintain Anonymity.

\section{Funding}

No fund was obtained for this study.

\section{Publisher's Note}

Springer Nature remains neutral with regard to jurisdictional claims in published maps and institutional affiliations.

Received: 6 September 2018 Accepted: 4 January 2019

Published online: 14 January 2019

\section{References}

1. Food U, Administration D. Managing food safety: a manual for the voluntary use of HACCP principles for operators of food service and retail establishments. New York: FAO; 2012.

2. Tessema AG, Gelaye KA, Chercos DH. Factors affecting food handling Practices among food handlers of Dangila town food and drink establishments, North West Ethiopia. BMC Public Health. 2014;14(1):571.

3. Organization $\mathrm{WH}$. Health surveillance and management procedures for food-handling personnel: report of a WHO consultation [held in Geneva from 18 to 22 April 1988]. Geneva:WHO; 1989.

4. Lee HK, Abdul Halim H, Thong KL, Chai LC. Assessment of food safety knowledge, attitude, self-reported practices, and microbiological hand hygiene of food handlers. Int J Environ Res Public Health. 2017;14(1):55.

5. Organization WH. WHO estimates of the global burden of foodborne diseases: foodborne disease burden epidemiology reference group 2007-2015. Geneva: WHO; 2015

6. Scallan E, Hoekstra RM, Angulo FJ, Tauxe RV, Widdowson M-A, Roy SL, et al. Foodborne illness acquired in the United States-major pathogens. Emerg Infect Dis. 2011;17(1):7.

7. World Health Organization ROfS-EA. Burden of foodborne diseases in the South-East Asia Region. Geneva:WHO; 2016. p. 47.

8. Mensah P, Mwamakamba L, Mohamed C, Nsue-Milang D. Public health and food safety in the WHO African region. Afr J Food Agric Nutr Dev. 2012;12(4):6317-35

9. Ayalew H, Birhanu A, Asrade B. Review on food safety system: Ethiopian perspective. Afr J Food Sci. 2013;7(12):431-40.

10. Authority $\mathrm{OH}$, Protection $\mathrm{CH}$, Program FIP. Food safety your self-training manual. New York: FAO; 2012. p. 43.

11. Aklilu A, Kahase D, Dessalegn M, Tarekegn N, Gebremichael S, Zenebe S, et al. Prevalence of intestinal parasites, salmonella and shigella among apparently health food handlers of Addis Ababa University student's cafeteria, Addis Ababa, Ethiopia. BMC Res Notes. 2015:8(1):17.

12. Tefera T, Mebrie G. Prevalence and predictors of intestinal parasites among food handlers in Yebu town, southwest Ethiopia. PLoS ONE. 2014;9(10):e110621.

13. Mama M, Alemu G. Prevalence and factors associated with intestinal parasitic infections among food handlers of Southern Ethiopia: cross sectional study. BMC Public Health. 2016;16(1):105. 
14. Gizaw Z, Gebrehiwot M, Teka Z. Food safety practice and associated factors of food handlers working in substandard food establishments in Gondar Town, Northwest Ethiopia, 2013/14. Int J Food Sci Nutr Diet. 2014;3(7):138-46.

15. Legesse D, Tilahun M, Agedew E, Haftu D. Food handling practices and associated factors among food handlers in arba minch town public food establishments in Gamo Gofa Zone, Southern Ethiopia. Epidemiology. 2017;7:2.

16. Getachew M. Food safety practice and associated factors among food handlers in selected types of food establishments of Dire Dawa, Ethiopia. New York: FAO; 2016. p. 41.

17. Thelwell-Reid MA. Food safety knowledge and self-reported practices of food handlers in Jamaica. Walden: Walden University Scholar Works; 2014 p. 188.

18. Iwu AC, Uwakwe KA, Duru CB, Diwe KC, Chineke HN, Merenu IA, et al. Knowledge, attitude and practices of food hygiene among food vendors in Owerri, Imo State, Nigeria. Occup Dis Environ Med. 2017;5(01):11.

19. Nee SO, Sani NA. Assessment of knowledge, attitudes and practices (KAP) among food handlers at residential colleges and canteen regarding food safety. Sains Malaysiana. 2011;40(4):403-10

20. Sharif L, Obaidat MM, Al-Dalalah M-R. Food hygiene knowledge, attitudes and practices of the food handlers in the military hospitals. Food Nutr Sci. 2013;4(03):245
21. Meleko A, Henok A, Tefera W, Lamaro T. Assessment of the sanitary conditions of catering establishments and food safety knowledge and practices of food handlers in Addis Ababa University Students' Cafeteria. Science. 2015;3(5):733-43.

22. Henson S, Humphrey J. The Impacts of Private Food Safety Standards on the Food Chain and on Public Standard-Setting Processes codex alimentarius commission joint FAO/WHO food standards programme. Rome: FAO Headquarters; 2009.

23. Buccheri C, Casuccio A, Giammanco S, Giammanco M, La Guardia M, Mammina C. Food safety in hospital: knowledge, attitudes and practices of nursing staff of two hospitals in Sicily, Italy. BMC Health Serv Res. 2007;7(1):45.

24. Akabanda F, Hlortsi EH, Owusu-Kwarteng J. Food safety knowledge, attitudes and practices of institutional food-handlers in Ghana. BMC Public Health. 2017;17(1):40.

25. Afolaranmi TO, Hassan ZI, Bello DA, Misari Z. Knowledge and practice of food safety and hygiene among food vendors in primary schools in Jos, Plateau State, North Central Nigeria. J Med Res. 2015;4(2):016-22.

26. Mary T. Article 81 of the NYC health code. New York: Food Preparation and Food Establishments; 2017. p. 1-49.
Ready to submit your research? Choose BMC and benefit from:

- fast, convenient online submission

- thorough peer review by experienced researchers in your field

- rapid publication on acceptance

- support for research data, including large and complex data types

- gold Open Access which fosters wider collaboration and increased citations

- maximum visibility for your research: over 100M website views per year

At BMC, research is always in progress.

Learn more biomedcentral.com/submissions 